\title{
Correction to: LY2963016 Insulin Glargine: A Review in Type 1 and 2 Diabetes
}

\author{
Yvette N. Lamb ${ }^{1} \cdot$ Yahiya Y. Syed $^{1}$
}

Published online: 6 March 2018

(C) Springer International Publishing AG, part of Springer Nature 2018

Correction to: BioDrugs 2018; 32 (1): 91-98. https://doi.org/10.1007/s40259-018-0259-4

Page 91, abstract, lines 1-6: The following sentence, which previously read:

Subcutaneous once-daily LY2963016 insulin glargine (LY insulin glargine) [Abasaglar ${ }^{\circledR}$ (EU); Basaglar $\left.^{(}\right)$(USA)] has been approved in the EU as a biosimilar to reference insulin glargine (Lantus ${ }^{\circledR}$ ), and in the USA as a follow-on biologic to reference insulin glargine, for use in patients with type 1 or 2 diabetes.

should read:

Subcutaneous once-daily LY2963016 insulin glargine $100 \mathrm{U} / \mathrm{mL}$ (LY insulin glargine) [Abasaglar ${ }^{\circledR}$ (EU); Basaglar $^{\circledR}$ (USA)] has been approved in the EU as a biosimilar to insulin glargine $100 \mathrm{U} / \mathrm{mL}$ (Lantus ${ }^{\circledR}$ ) [reference insulin glargine], and in the USA as a follow-on biologic to reference insulin glargine, for use in patients with type 1 or 2 diabetes.

Pages 91-2, section 1, paragraph 1, lines 4-10: The following sentence, which previously read:

Subcutaneous once-daily insulin glargine $100 \mathrm{U} / \mathrm{mL}$ (Lantus ${ }^{\circledR}$ ) is an established effective and well-tolerated basal insulin therapy in patients with type 1 or 2 diabetes [1]. Following the recent expiration of patents for insulin glargine, biosimilars of insulin glargine developed by other pharmaceutical companies are beginning to enter highly regulated markets $[1,2]$.

should read:

Subcutaneous once-daily insulin glargine $100 \mathrm{U} / \mathrm{mL}$ (Lantus ${ }^{\circledR}$ ) [reference insulin glargine] is an established effective and well-tolerated basal insulin therapy in patients with type 1 or 2 diabetes [1]. Following the recent expiration of patents for reference insulin glargine, biosimilars of insulin glargine developed by other pharmaceutical companies are beginning to enter highly regulated markets $[1,2]$.

Page 92, section 1, paragraph 2, lines 1-4: The following sentence, which previously read:

Subcutaneous once-daily LY2963016 insulin glargine (LY insulin glargine) $100 \mathrm{U} / \mathrm{mL}$ [Abasaglar ${ }^{\circledR}$ (EU); Basaglar $^{\circledR}$ (USA)] is a long-acting insulin analogue that is biosimilar to reference insulin glargine $100 \mathrm{U} / \mathrm{mL}$.

should read:

Subcutaneous once-daily LY2963016 insulin glargine $100 \mathrm{U} / \mathrm{mL}$ [Abasaglar ${ }^{\circledR}$ (EU); Basaglar ${ }^{\circledR}$ (USA)] (LY insulin glargine) is a long-acting insulin analogue that is biosimilar to reference insulin glargine.
The original article can be found online at https://doi.org/10.1007/ s40259-018-0259-4.

Yvette N. Lamb demail@springer.com

1 Springer, Private Bag 65901, Mairangi Bay, 0754 Auckland, New Zealand 